\title{
Rhizobium lusitanum sp. nov. a bacterium that nodulates Phaseolus vulgaris
}

\author{
Angel Valverde, ${ }^{1} \dagger$ José M. Igual, ${ }^{1}$ Alvaro Peix, ${ }^{1}$ Emilio Cervantes ${ }^{1}$ \\ and Encarna Velázquez ${ }^{2}$ \\ ${ }^{1}$ Departamento de Producción Vegetal, IRNASA-CSIC, Salamanca, Spain \\ ${ }^{2}$ Departamento de Microbiología y Genética, Universidad de Salamanca, Spain
}

Correspondence

Encarna Velázquez

evp@usal.es
The species Phaseolus vulgaris is a promiscuous legume nodulated by several species of the family Rhizobiaceae. During a study of rhizobia nodulating this legume in Portugal, we isolated several strains that nodulate $P$. vulgaris effectively and also Macroptilium atropurpureum and Leucaena leucocephala, but they form ineffective nodules in Medicago sativa. According to phylogenetic analysis of the 16S rRNA gene sequence, the strains from this study belong to the genus Rhizobium, with Rhizobium rhizogenes and Rhizobium tropici as the closest related species, with 99.9 and $99.2 \%$ similarity, respectively, between the type strains of these species and strain $\mathrm{P} 1-7^{\top}$. The nodD and nifH genes carried by strain $\mathrm{P} 1-7^{\top}$ are phylogenetically related to those of other species nodulating Phaseolus. This strain does not carry virulence genes present in the type strain of $R$. rhizogenes, ATCC $11325^{\top}$. Analysis of the recA and atpD genes confirms this phylogenetic arrangement, showing low similarity with respect to those of $R$. rhizogenes ATCC $11325^{\top}\left(91.9\right.$ and $94 \cdot 1 \%$ similarity, respectively) and $R$. tropici IIB CIAT $899^{\top}(90 \cdot 6 \%$ and $91.8 \%$ similarity, respectively). The intergenic spacer (ITS) of the strains from this study is phylogenetically divergent from those of $R$. rhizogenes ATCC $11235^{\top}$ and $R$. tropici CIAT $899^{\top}$, with 85.9 and $82.8 \%$ similarity, respectively, with respect to strain $\mathrm{P} 1-7^{\top}$. The tRNA profile and two-primer random amplified polymorphic DNA pattern of strain $\mathrm{P} 1-7^{\top}$ are also different from those of $R$. rhizogenes ATCC $11235^{\top}$ and R. tropici CIAT $899^{\top}$. The strains isolated in this study can be also differentiated from $R$. rhizogenes and $R$. tropici by several phenotypic characteristics. The results of DNA-DNA hybridization showed means of 28 and $25 \%$ similarity between strain $\mathrm{P} 1-7^{\top}$ and $R$. rhizogenes ATCC $11235^{\top}$ and R. tropici CIAT $899^{\top}$, respectively. All these data showed that the strains isolated in this study belong to a novel species of the genus Rhizobium, for which we propose the name Rhizobium lusitanum sp. nov.; the type strain is P1-7 ${ }^{\top}$ (= LMG $22705^{\top}=\mathrm{CECT}^{\circ}$ $\left.7016^{\top}\right)$.
The common bean (Phaseolus vulgaris) is a legume indigenous to Mesoamerica and the Andean region of South America that is extensively cultivated throughout the world (Martínez-Romero, 2003). It constitutes a staple cultivation in many developing countries. This legume is considered as a promiscuous host, since it can be nodulated

†Present address: Department of Plant Pathology and Microbiology, Faculty of Agricultural, Food and Environmental Quality Sciences, The Hebrew University of Jerusalem, Rehovot 76100, Israel.

Abbreviations: LMW RNA, low molecular weight RNA; TP-RAPD, twoprimer random amplified polymorphic DNA.

The GenBank/EMBL/DDBJ accession numbers for the 16S rRNA, nodD and nifH gene sequences of strain $P 1-7^{\top}$ are $A Y 738130$, AY943643 and AY943644, respectively.

A number of additional figures and a table detailing DNA-DNA hybridization results are available as supplementary material in IJSEM Online. by several rhizobial species. To date, six species belonging to the genus Rhizobium have been identified as endosymbionts of common bean (Amarger et al., 1997; Jordan, 1984; Martínez-Romero et al., 1991; Segovia et al., 1993; Velázquez et al., 2001b) but some other species, from this and other rhizobial genera, have been also described as infective under experimental conditions (MartínezRomero, 2003). The diversity of rhizobia nodulating $P$. vulgaris has been widely studied, but, because of its promiscuous nature, novel endosymbionts of this legume should be expected as more ecological niches are studied. In the present work, we analysed several strains nodulating common bean in several soils from the region of Arcos de Valdevez, in the north-west of Portugal, where a traditional mixed farming system, with livestock and crops integrated into a single ecosystem, and local varieties of common beans have been used for centuries. A polyphasic study of these strains, including phenotypic and molecular taxonomic 
approaches, showed that they belong to a novel species of the genus Rhizobium phylogenetically close to Rhizobium rhizogenes and Rhizobium tropici.

In this study, 22 strains (Table 1) were isolated from $P$. vulgaris plants growing in three soils from the north-west of Portugal (Arcos de Valdevez region) with different chemical characteristics (data not shown). For isolation of bacterial strains, nodules present in $P$. vulgaris roots were surface sterilized using a $2.5 \%$ aqueous solution of $\mathrm{HgCl}_{2}$ for $2 \mathrm{~min}$. The nodules were then washed ten times with sterile water, disrupted in sterile water and cultivated in YMA medium (Bergersen, 1961) at $28^{\circ} \mathrm{C}$ for 4 days. To test the symbiotic characteristics of the new bacterial isolates, $P$. vulgaris, Leucaena leucocephala, Macroptilium atropurpureum and Medicago sativa plants were inoculated as described by Velázquez et al. (2001b), using $R$. tropici CIAT $899^{\mathrm{T}}$ as a control. All the novel strains were able to elicit effective nodules in P. vulgaris, Macroptilium atropurpureum and $L$. leucocephala and ineffective nodules in Medicago sativa. The ability to induce the production of roots on discs of Daucus carota was examined as described previously (Moore et al., 1979). The strains isolated in this study were unable to produce these symptoms.

The plasmid content was determined by the method of Plazinski et al. (1985), with the modifications described by Rivas et al. (2002b), using Ensifer meliloti GR4 as a reference (Toro \& Olivares, 1986). The results obtained (see
Supplementary Fig. S1 in IJSEM Online) showed that the strains from this study present seven different plasmid profiles (see Table 1) containing between one and four plasmids, the sizes of which ranged from approximately 90 to $1700 \mathrm{~kb}$, some of which are megaplasmids $(>1000 \mathrm{~kb})$.

The nodD and nifH genes harboured by strain $\mathrm{P} 1-7^{\mathrm{T}}$ were amplified and sequenced as described previously (Rivas et al., 2002b). According to nodD and nifH gene sequences, the closest relative of strain $\mathrm{P} 1-7^{\mathrm{T}}$ is Devosia neptuniae $\mathrm{J1}^{\mathrm{T}}$, showing 99.6 and $99.5 \%$ similarity, respectively (Supplementary Figs S2 and S3). The same genes from $R$. tropici CIAT $899^{\mathrm{T}}$ showed $99 \cdot 2$ and $99 \cdot 5 \%$ similarity, respectively. In a previous work (Rivas et al., 2002b), we have already shown the high similarity of the nodD and nifH genes carried by $D$. neptuniae $\mathrm{J}^{\mathrm{T}}$ and those of $R$. tropici CIAT $899^{\mathrm{T}}$. These results are in agreement with those obtained in the analysis of the host range of strain $\mathrm{P} 1-\mathrm{7}^{\mathrm{T}}$, because it was able to nodulate Phaseolus and Leucaena, two common hosts for R. tropici (Martínez-Romero et al., 1991). Nevertheless, the nodD and nifH genes recently sequenced in $R$. rhizogenes ATCC $11325^{\mathrm{T}}$ are phylogenetically distant from those of strain $\mathrm{P} 1-7^{\mathrm{T}}$, strongly supporting our previous hypothesis that $P$. vulgaris was not the ancestral host of $R$. rhizogenes (Velázquez et al., 2005).

The presence of the virA gene in strain $\mathrm{P} 1-7^{\mathrm{T}}$ was analysed using the primers and PCR conditions described previously (Velázquez et al., 2005). The results were negative,

Table 1. Differential genotypic characteristics of the novel strains (Rhizobium lusitanum sp. nov.) and phylogenetically closely related Rhizobium species

\begin{tabular}{|c|c|c|c|c|c|c|}
\hline Strain & $\begin{array}{l}\text { TP-RAPD } \\
\text { type }\end{array}$ & $\begin{array}{l}\text { RAPD } \\
\text { type }\end{array}$ & $\begin{array}{c}\text { ITS } \\
\text { profile }\end{array}$ & $\begin{array}{l}\text { LMW RNA } \\
\text { profile }\end{array}$ & $\begin{array}{l}\text { Sequence identity } \\
\text { (ungapped) to strain } \mathrm{P} 1-7^{\mathrm{T}_{\star}}\end{array}$ & Plasmid profile \\
\hline \multicolumn{7}{|l|}{ Rhizobium lusitanum sp. nov. } \\
\hline $\mathrm{P} 1-7^{\mathrm{T}}, \mathrm{P} 6-18, \mathrm{P} 6-20$ & A & I & $\mathrm{a}$ & 1 & $100,100,100,100$ & A \\
\hline P1-16, P1-17, P1-18, P1-19, P1-21, P1-22 & A & $\mathrm{I}$ & a & 1 & $100,100,100,100$ & B \\
\hline $\begin{array}{l}\text { P3-12, P3-13, P3-15, P3-16, P3-17, P3-18, } \\
\text { P3-19 }\end{array}$ & A & II & a & 1 & $100,99 \cdot 5,98 \cdot 5,98 \cdot 5$ & $\mathrm{C}$ \\
\hline P3-20, P3-21, P3-25 & A & I & a & 1 & $100,100,100,100$ & $\mathrm{D}$ \\
\hline P3-24 & A & I & a & 1 & $100,100,100,100$ & $\mathrm{E}$ \\
\hline P6-7 & A & $\mathrm{I}$ & a & 1 & $100,100,100,100$ & $\mathrm{~F}$ \\
\hline P6-8 & A & I & a & 1 & $100,100,100,100$ & G \\
\hline \multicolumn{7}{|l|}{ Rhizobium tropici } \\
\hline CFN 299 (IIA) & B & VIII & $\mathrm{b}$ & 4 & $99 \cdot 6,84 \cdot 3,92 \cdot 3,92 \cdot 0$ & $\begin{array}{c}\text { Acosta-Durán \& } \\
\text { Martínez-Romero (2002) }\end{array}$ \\
\hline CIAT $899^{\mathrm{T}}$ (IIB) & $\mathrm{D}$ & VI & c & 3 & $99 \cdot 2,82 \cdot 8,91 \cdot 8,90 \cdot 6$ & $\begin{array}{c}\text { Acosta-Durán \& } \\
\text { Martínez-Romero (2002) }\end{array}$ \\
\hline Br859 (IIB) & $\mathrm{D}$ & VII & c & 3 & $\mathrm{ND}, 83 \cdot 9,92 \cdot 4,90 \cdot 7$ & ND \\
\hline \multicolumn{7}{|l|}{ Rhizobium rhizogenes } \\
\hline IAM 13571 & $\mathrm{C}$ & III & a & 2 & $\mathrm{ND}, 87 \cdot 1,93 \cdot 7,91 \cdot 8$ & ND \\
\hline $163 \mathrm{C}$ & $\mathrm{C}$ & IV & a & 2 & $99 \cdot 9,89 \cdot 8,93 \cdot 4,91 \cdot 8$ & Velázquez et al. (2005) \\
\hline ATCC $11325^{\mathrm{T}}$ & $\mathrm{C}$ & $\mathrm{V}$ & a & 2 & $99 \cdot 9,85 \cdot 9,94 \cdot 1,91 \cdot 9$ & Velázquez et al. (2005) \\
\hline
\end{tabular}

ND, No data available.

${ }^{\star}$ Values respectively represent similarity for the $16 \mathrm{~S}$ rRNA gene, ITS and atpD and recA genes. 
coinciding with the inability of our strains to induce pathogenicity symptoms in plants.

The diversity of strains isolated in this study was assessed by randomly amplified polymorphic DNA (RAPD) pattern analysis using the primer M13 (5'-GAGGGTGGCGGTTCT-3') as described previously (Igual et al., 2003). Two different RAPD patterns were found among the 22 strains isolated from the three studied soils (Supplementary Fig. S4). Most of them showed RAPD pattern I (lanes 1-15), whereas seven strains showed pattern II (lanes 16-22). The remaining strains used in this study (lanes 23-28) presented different RAPD patterns (see Table 1).

The RAPD patterns are strain dependent and therefore they are useful in analysing the intraspecific diversity of a rhizobial population (Corich et al., 2001; Moschetti et al., 2005). Other PCR-based profiles, such as two-primer RAPD (TP-RAPD) patterns, are not strain dependent and, according to our previous studies (Rivas et al., 2001, 2004; Zurdo-Piñeiro et al., 2004), are useful in differentiating among rhizobial species. TP-RAPD patterns were analysed according to the method described by Rivas et al. (2002a) using the primers 879F (5'-GCCTGGGGAGTACGGCCGCA-3') and 1522R (5'-AAGGAGGTGATCCANCCRCA-3'), which correspond to Escherichia coli positions $879-898$ and $1509-1522$, respectively. The DNA patterns obtained contain a band that corresponded to the fragment of the 16S rRNA gene amplified with these two primers and several others produced by random amplification on the total DNA (Rivas et al., 2001). In a previous work, we demonstrated that all strains that show identical TP-RAPD pattern belong to the same species. No variations were observed in these patterns in strains from the same species with different plasmid profiles, and they do not vary with the growth phase (Rivas et al., 2001). All the strains isolated in this study presented the same TP-RAPD pattern (see Table 1 and Supplementary Fig. S5) and, therefore, all of them belong to the same bacterial species. This pattern (lanes 1-22) was different from those from strains of $R$. tropici IIB (lanes 25 and 28), R. tropici IIA (lane 23) and $R$. rhizogenes (lanes 24, 26 and 27), which are the closest phylogenetically related species on the basis of the $16 \mathrm{~S}$ rRNA, $r e c A$ and atpD gene sequences as well as the 16S-23S intergenic spacer (ITS) sequences (see below).
Strains $\mathrm{P} 1-7^{\mathrm{T}}$ and $\mathrm{P} 3-13$, which presented different RAPD patterns, were selected for analysis of $16 \mathrm{~S}$ rRNA, atpD and $r e c A$ gene sequences, analysis of the ITS sequence and DNADNA hybridization experiments.

Nearly complete $16 \mathrm{~S}$ rRNA gene sequences were obtained in this study according to the method described previously by Rivas et al. (2002b). Sequences of the recA and atpD genes were obtained according to Gaunt et al. (2001). The ITS region was amplified and sequenced as described by Kwon et al. (2005). These sequences were compared with those held in GenBank using the BLASTN program (Altschul et al., 1990). 16S rRNA gene sequences were aligned using the CLUSTAL W software (Thompson et al., 1997) and distances were calculated according to the models of Jukes \& Cantor (1969), Kimura (1980), Tajima \& Nei (1984) and Tamura \& Nei (1993). Phylogenetic trees were inferred using the neighbour-joining method (Saitou \& Nei, 1987), minimum evolution (Rzhetsky \& Nei, 1993) and parsimony analysis (Felsenstein, 1983). Bootstrap analysis was based on 1000 resamplings. The MEGA2 package (Kumar et al., 2001) was used for all analyses. As no significant topological differences were found among the phylogenetic trees obtained by the different methods assayed, only those trees constructed by using the neighbour-joining method after distance analysis of aligned sequences according to Kimura's two parameters (ITS and 16S rRNA gene) or Tamura-Nei (recA and atpD genes) models are shown.

The 16S rRNA gene sequences of strains $\mathrm{P} 1-7^{\mathrm{T}}$ and P3-13 exhibit $100 \%$ similarity and, thus, only the type strain was included in the phylogenetic analysis. The resulting neighbour-joining tree corresponding to 16S rRNA gene sequences is shown in Fig. 1 (a fuller phylogenetic tree is available as Supplementary Fig. S6). The results of the phylogenetic analysis indicate that the strains from this study are related to members of the genus Rhizobium within the family Rhizobiaceae. According to the 16S rRNA gene sequences, the closest relative to strain $\mathrm{P} 1-7^{\mathrm{T}}$ is $R$. rhizogenes ATCC $11325^{\mathrm{T}}$, showing $99.9 \%$ similarity, followed by $R$. tropici IIB CIAT $899^{\mathrm{T}}$, with $99 \cdot 2 \%$ similarity. $R$. tropici IIA CFN 299 showed $99.6 \%$ similarity $(95.0 \%$ when an insertion of 72 nucleotides at the beginning of the $16 \mathrm{~S}$ rRNA gene is considered).

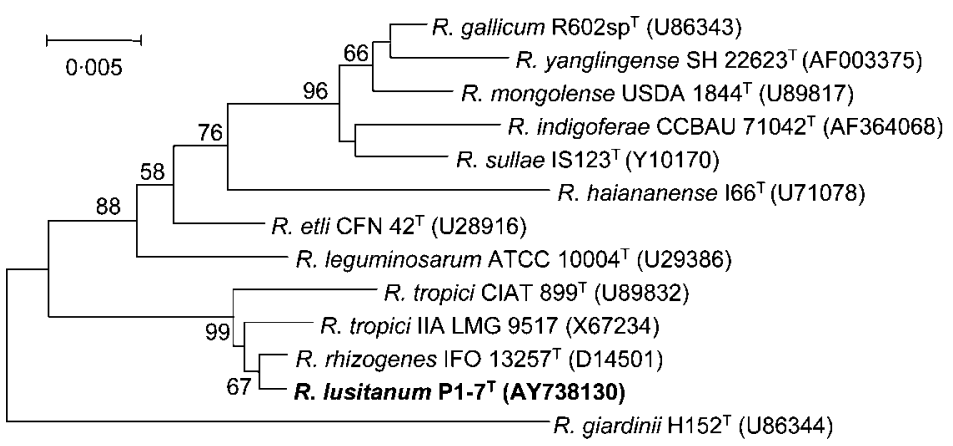

Fig. 1. Neighbour-joining tree based on nearly complete $16 \mathrm{~S}$ rRNA gene sequences of strain $\mathrm{P} 1-7^{\top}$ (Rhizobium lusitanum sp. nov.) and closely related species within the genus Rhizobium. The significance of each branch is indicated by a bootstrap value calculated for 1000 subsets. Bar, 5 substitutions per 1000 nt. 
According to the results of Gaunt et al. (2001), recA and atpD gene-based phylogenies of members of the family Rhizobiaceae are congruent with the 16S rRNA gene-based phylogeny. Although more studies on the variability of these genes will be necessary to establish the similarity range between strains from the same species and those of different species from the same genus within the family Rhizobiaceae, it seems that they are very useful in the classification and identification of rhizobial isolates (Vinuesa et al., 2005a, b). Thus, to confirm the phylogenetic position of the strains isolated in this study, we sequenced their $\operatorname{rec} A$ and $a t p D$ genes (Supplementary Figs S7 and S8). The results obtained completely confirm the phylogenetic position of these strains within the group $R$. rhizogenes $-R$. tropici and, moreover, the $\operatorname{rec} A$ and atp $D$ sequence similarities between strains $\mathrm{P} 1-7^{\mathrm{T}}$ and $\mathrm{P} 3-13$ were near to $98 \cdot 5 \%$ for both genes, demonstrating that these two strains are not clones. The sequence similarities between strain $\mathrm{P} 1-7^{\mathrm{T}}$ and $R$. rhizogenes ATCC $11325^{\mathrm{T}}$, R. tropici IIA CFN 299 and R. tropici IIB CIAT $899^{\mathrm{T}}$ were, respectively, $91 \cdot 9,92 \cdot 0$ and $90 \cdot 6 \%$ for $\mathrm{rec} A$ and $94 \cdot 1,92 \cdot 3$ and $91 \cdot 8 \%$ for atpD. These values are similar to those found between other phylogenetically close species of the genera Rhizobium and Ensifer, such as between Rhizobium leguminosarum and Rhizobium etli or between $E$. meliloti and Ensifer medicae (Gaunt et al., 2001). These similarity values with respect to $R$. rhizogenes and $R$. tropici suggest that the strains isolated in this study may belong to a novel species.

Comparison of 16S-23S rRNA ITS regions provides a fast tool to assess relatedness between closely related rhizobial strains (Kwon et al., 2005). This region was sequenced in the strains P1-7 ${ }^{\mathrm{T}}$ and P3-13, representative of each of the two RAPD groups. The length of the fragment obtained in both strains was $1281 \mathrm{bp}$ and their sequence similarity was $99 \cdot 5 \%$. The same length was obtained for $R$. rhizogenes ATCC $11325^{\mathrm{T}}$; however, the ITS regions of $R$. tropici IIA CFN 299 and $R$. tropici IIB CIAT $899^{\mathrm{T}}$ were, respectively, 130 and $190 \mathrm{bp}$ shorter (Supplementary Fig. S9). After a pairwise analysis, the ITS sequence of strain $\mathrm{P} 1-7^{\mathrm{T}}$ showed $85.9 \%$ ( $73.0 \%$ including gaps), $84.3 \%$ (70.9\% including gaps) and $82.8 \%(66.3 \%$ including gaps) similarity with respect to those of $R$. rhizogenes ATCC $11325^{\mathrm{T}}, R$. tropici IIA CFN 299 and $R$. tropici IIB CIAT $899^{\mathrm{T}}$, respectively. In agreement with the phylogenetic analyses based on the $16 \mathrm{~S}$ rRNA, atpD and recA gene sequences, phylogenetic analysis of ITS sequences also demonstrated that the strains from this study belong to the $R$. rhizogenes $-R$. tropici cluster (Supplementary Fig. S10). However, differences in the nucleotide sequence between the type strains of these two species and strain $\mathrm{P} 1-7^{\mathrm{T}}$ suggest that the strains isolated in this study belong to a different species, which is in concordance with other results from this work.

Although discordant phylogenies have been reported within the rrn (16S rRNA) locus in some rhizobial species (van Berkum et al., 2003), the results here obtained on the basis of $r r n, r e c A$ and atpD sequence analyses show a complete concordance in the phylogenetic location of the strains isolated in this study within the cluster $R$. rhizogenes $-R$. tropici. In order to confirm these phylogenetic data we also analysed the low-molecular-weight (LMW) RNA profiles of the isolated strains (Supplementary Fig. S11), as was described recently (Velázquez et al., 2006). These profiles contain three clearly distinguishable zones. The 5S rRNA zone is identical in species from the same genus, as occurs in the case of strain $\mathrm{P} 1-7^{\mathrm{T}}, R$. rhizogenes ATCC $11325^{\mathrm{T}}$, $R$. tropici IIB CIAT $899^{\mathrm{T}}$ and $R$. tropici IIA CFN 299 (Supplementary Fig. S11, lanes 1-4, respectively). The class 1 and 2 tRNAs are different in different species from the same or different genera and the differences are related to phylogenetic distances on basis of the 16S rRNA gene sequences (Velázquez et al., 2001d). As expected, the tRNA profiles of all of the novel strains were identical (data not shown). As can be seen in Supplementary Fig. S11, the tRNA profile of strain $\mathrm{P} 1-7^{\mathrm{T}}$ (lane 1) has only one band different from $R$. rhizogenes ATCC $11325^{\mathrm{T}}$ (lane 2), whereas many differences are observed with respect to the tRNA profiles of R. tropici IIB CIAT $899^{\mathrm{T}}$ (lane 3) and R. tropici IIA CFN 299 (lane 4). These results confirmed the placement of the strains from this study in the group of $R$. rhizogenes and $R$. tropici, being the most closely related species to the novel strains. The existence of a different tRNA band between the novel strains and $R$. rhizogenes supports the hypothesis that the strains isolated in this study do not belong to $R$. rhizogenes, since a single difference in tRNA profiles has been proposed to be diagnostic in bacterial species differentiation (Höfle, 1990). Moreover, the different LMW RNA profiles showed by the strains belonging to the subgroups IIA and IIB of $R$. tropici, in addition to the results from ITS, $16 \mathrm{~S}$ rRNA, recA and atpD sequence analyses, as well as the DNADNA hybridization results (see below), indicate that they belong to different species.

DNA-DNA hybridization was carried out by using the method of Ezaki et al. (1989), following the recommendations of Willems et al. (2001). Strains $\mathrm{P} 1-7^{\mathrm{T}}$ and P3-13 were hybridized with two strains from the subgroup IIB of R. tropici, CIAT $899^{\mathrm{T}}$ and Br859 (Martínez-Romero et al., 1991), which presented the same TP-RAPD pattern (Supplementary Fig. S5, lanes 25 and 28) but different RAPD pattern (Supplementary Fig. S4, lanes 26 and 27), with $R$. tropici IIA CFN 299 (Supplementary Figs S5 and S4, lanes 23 and 28, respectively) and with three strains of R. rhizogenes, IAM 13571 (de Oliveira et al., 1999), ATCC $11325^{\mathrm{T}}$ and 163C (Velázquez et al., 2005), which presented the same TP-RAPD pattern (Supplementary Fig. S5, lanes 24, 26 and 27) but different RAPD patterns (Supplementary Fig. S4, lanes 23-25). Strains $\mathrm{P} 1-7^{\mathrm{T}}$ and P3-13 showed hybridization values of 90-100\% (Supplementary Table S1). DNA-DNA hybridization between either of these strains and strains belonging to the species $R$. rhizogenes or $R$. tropici always yielded values of $43 \%$ or lower. These results indicate that the strains from this study do not belong to either of these recognized species when the recommendation of a threshold value of $70 \%$ DNA-DNA 
relatedness for species definition is considered (Wayne et al., 1987).

For base composition analysis, DNA was prepared according to Chun \& Goodfellow (1995). The G + C content of DNA of strain $\mathrm{P} 1-\mathrm{7}^{\mathrm{T}}$ was determined using the thermal denaturation method (Mandel \& Marmur, 1968) as $65 \cdot 15 \mathrm{~mol} \%$. This value is similar to those obtained for other Rhizobium species (Jordan, 1984).

Phenotypic characterization of the strains was based on growth with different carbon and nitrogen sources, the production of exoenzymes and resistance to different antibiotics as described previously (Kersters \& De Ley, 1984, Velázquez et al., 2001a, b; Zurdo-Piñeiro et al., 2004) and by using an API 20NE kit according to the manufacturer's instructions (bioMérieux). For testing antibiotic resistance, the following antibiotics were used: ampicillin $(2 \mu \mathrm{g})$, erythromycin $(2 \mu \mathrm{g})$, ciprofloxacin $(5 \mu \mathrm{g})$, penicillin (10 IU), polymyxin (300 IU), cloxacillin $(1 \mu \mathrm{g})$, oxytetracycline $(30 \mu \mathrm{g})$, gentamicin $(10 \mu \mathrm{g})$, cefuroxime $(30 \mu \mathrm{g})$ and neomycin $(5 \mu \mathrm{g})$ (Becton Dikinson). The basal medium was YMA (Vincent, 1970) supplemented with 10 g yeast extract $l^{-1}$. The temperature range for growth was determined by incubating cultures in YMA medium between 4 and $45^{\circ} \mathrm{C}$. The $\mathrm{pH}$ range was determined in the same medium with a final $\mathrm{pH}$ between $4 \cdot 0$ and $10 \cdot 0$. Salt tolerance was studied in YMA medium containing 0-5\% $(\mathrm{w} / \mathrm{v}) \mathrm{NaCl}$. R. rhizogenes ATCC $11325^{\mathrm{T}}$, R. tropici IIB CIAT $899^{\mathrm{T}}$ and $R$. tropici IIA CFN 299 were used as reference strains. All of the novel strains had the same phenotypic characteristics, but they showed several differences compared with their closest relatives, $R$. rhizogenes and $R$. tropici (Table 2). They differ from $R$. rhizogenes in growth at $35^{\circ} \mathrm{C}$, growth in Luria-Bertani (LB) medium, resistance to penicillin, oxytetracycline and cefuroxime and in the ability to induce hairy roots in Daucus carota. They differ from subgroup IIB of $R$. tropici in growth at $40^{\circ} \mathrm{C}$, assimilation of adipate as a carbon source, production of $\alpha$-fucosidases and resistance to oxytetracycline and polymyxin B. Finally, they differ from subgroup IIA of $R$. tropici in growth in PY without calcium and LB media, production of $\beta$-galactosaminidases, $\beta$-cellobiases, $\alpha$-fucosidases and $\beta$-maltosidases and resistance to erythromycin, oxytetracycline and cefuroxime.

Therefore, the novel group can be differentiated genotypically and phenotypically from previously described species and we therefore propose to name it Rhizobium lusitanum sp. nov.

\section{Description of Rhizobium lusitanum sp. nov.}

Rhizobium lusitanum (lu.si.ta' num. L. neut. adj. lusitanum of Lusitania, the Roman name of Portugal, where the strains reported in this study were isolated).

Gram-negative rods, as for the other species of the genus. Colonies are small, pearl white on YMA at $28^{\circ} \mathrm{C}$, which is the optimal growth temperature. The optimum $\mathrm{pH}$ is $7-7 \cdot 5$.
Table 2. Differential characteristics of the novel strains (Rhizobium lusitanum sp. nov.) and the closest related species

Taxa: 1, R. tropici IIB; 2, R. tropici IIA; 3, R. rhizogenes; 4, R. lusitanum sp. nov. Data were taken from Amarger et al. (1997), Jordan (1984), Kersters \& De Ley (1984), Martínez-Romero et al. (1991) and Young et al. (2001) and this study. +, Positive; -, negative; w, weak; pNP, $p$-nitrophenyl; ND, no data available.

\begin{tabular}{|c|c|c|c|c|}
\hline Characteristic & 1 & 2 & 3 & 4 \\
\hline \multicolumn{5}{|l|}{ Growth at/in: } \\
\hline $35^{\circ} \mathrm{C}$ & + & + & - & + \\
\hline $40^{\circ} \mathrm{C}$ & + & - & - & - \\
\hline LB medium & + & - & - & + \\
\hline PY medium lacking calcium & + & - & + & + \\
\hline Use of adipate as a carbon source & $+^{*}$ & $-\dagger$ & $-末$ & - \\
\hline \multicolumn{5}{|l|}{ Cleavage of: } \\
\hline pNP $\beta$-D-galactosaminide & $+^{*}$ & $-\dagger$ & $+\ddagger$ & + \\
\hline pNP $\beta$-D-cellobioside & $\mathrm{W}^{*}$ & $-\dagger$ & $+\ddagger$ & + \\
\hline pNP $\alpha$-L-fucopyranoside & $-{ }^{*}$ & $-\dagger$ & $+\ddagger$ & + \\
\hline $\mathrm{pNP} \beta$-D-maltopyranoside & $\mathrm{W}^{*}$ & $-\dagger$ & $+\ddagger$ & + \\
\hline $\mathrm{pNP}$ thio- $\beta$-D-glucopyranoside & $+^{*}$ & $-\dagger$ & $+\ddagger$ & + \\
\hline \multicolumn{5}{|l|}{ Resistance to: } \\
\hline Penicillin & $+^{*}$ & $+\dagger$ & $-末$ & + \\
\hline Erythromycin & + & - & $+\ddagger$ & + \\
\hline Oxytetracycline & - & - & -末 & + \\
\hline Cefuroxime & $+^{*}$ & $-\dagger$ & 一未 & + \\
\hline Polymyxin B & + & - & -末 & - \\
\hline Root formation on discs of $D$. carota & $\mathrm{ND}$ & $\mathrm{ND}$ & + & - \\
\hline
\end{tabular}

${ }^{\star}$ Data from Zurdo-Piñeiro et al. (2004) confirmed in this study. $\dagger$ Data from this study for R. tropici IIA CFN 299.

$\ddagger$ Data from this study for several strains included in Velázquez et al. (2001c).

Strains may grow between 10 and $37^{\circ} \mathrm{C}, \mathrm{pH} 5$ and 8 and weakly up to $1 \%(\mathrm{w} / \mathrm{v}) \mathrm{NaCl}$. Denitrification is carried out by the strains from this study. The strains produce $\beta$ galactosidase and urease and hydrolyse aesculin in the API $20 \mathrm{NE}$ system. They also produce $\alpha$ - and $\beta$-arabinosidases, $\alpha$ and $\beta$-galactosidases, $\beta$-galactosidaminidases, $\beta$-cellobiases, $\alpha$ - and $\beta$-xylosidases, $\alpha$-maltosidases and $\beta$-glucosaminidases using chromogenic $p$-nitrophenyl substrates. They do not produce indole, arginine dihydrolase or gelatinase in API 20NE. They use glucose, melezitose, ethanol, mesoerythritol, L-arabinose, mannose, fructose, galactose, Lrhamnose, xylose, $\mathrm{N}$-acetylglucosamine, maltose, sucrose, cellobiose, raffinose, melibiose, trehalose, salicin, inositol, mannitol, sorbitol, malate, gluconate and citrate as carbon sources. They grow on L-histidine, aspartate, glutamate and betaine as carbon and nitrogen sources. They grow weakly on L-lysine, xylitol and L-sorbose. They do not grow on caprate, adipate, phenylacetate, glucuronate, propionate, valine or L-alanine. All strains are resistant to ampicillin, erythromycin, cloxacillin, penicillin, cefuroxime and oxytetracycline. They do not grow in the presence of ciprofloxacin, polymyxin B or gentamicin. Growth is weak 
in the presence of neomycin. The $\mathrm{G}+\mathrm{C}$ content of strain $\mathrm{P} 1-$ $7^{\mathrm{T}}$ is $65 \cdot 15 \mathrm{~mol} \%$.

The type strain, $\mathrm{P} 1-7^{\mathrm{T}}\left(=\mathrm{LMG} 22705^{\mathrm{T}}=\mathrm{CECT} 7016^{\mathrm{T}}\right)$, was isolated from effective nodules of Phaseolus vulgaris in Portugal.

\section{Acknowledgements}

This work was initiated as a collaboration with Drs Fernanda Mesquita and Manuel Judice Halpern (Instituto Superior da Ciencias da Saude, Lisboa) in the framework of an INTERREG II project. This work was supported by Junta de Castilla y León and DGCYT (Spanish Government). We are grateful to M. Sánchez for 16S rRNA gene sequencing.

\section{References}

Acosta-Durán, C. \& Martínez-Romero, E. (2002). Diversity of rhizobia from nodules of the leguminous tree Gliricidia sepium, a natural host of Rhizobium tropici. Arch Microbiol 178, 161-164.

Altschul, S. F., Gish, W., Miller, W., Myers, E. W. \& Lipman, D. J. (1990). Basic local alignment search tool. J Mol Biol 215, 403-410.

Amarger, N., Macheret, V. \& Laguerre, G. (1997). Rhizobium gallicum sp. nov. and Rhizobium giardinii sp. nov., from Phaseolus vulgaris nodules. Int J Syst Bacteriol 47, 996-1006.

Bergersen, F. J. (1961). The growth of Rhizobium in synthetic media. Aust J Biol 14, 349-360.

Chun, J. \& Goodfellow, M. (1995). A phylogenetic analysis of the genus Nocardia with 16S rRNA gene sequences. Int J Syst Bacteriol 45, 240-245.

Corich, V., Giacomini, A., Carlot, M., Simon, R., Tichy, H. V., Squartini, A. \& Nuti, M. P. (2001). Comparative strain typing of Rhizobium leguminosarum bv. viciae natural populations. Can $J$ Microbiol 47, 580-584.

de Oliveira, V. M., Coutinho, H. L., Sobral, B. W., Guimaraes, C. T., van Elsas, J. D. \& Manfio, G. P. (1999). Discrimination of Rhizobium tropici and R. leguminosarum strains by PCR-specific amplification of 16S-23S rDNA spacer region fragments and denaturing gradient gel electrophoresis (DGGE). Lett Appl Microbiol 28, 137-141.

Ezaki, T., Hashimoto, Y. \& Yabuuchi, E. (1989). Fluorometric deoxyribonucleic acid-deoxyribonucleic acid hybridization in microdilution wells as an alternative to membrane filter hybridization in which radioisotopes are used to determine genetic relatedness among bacterial strains. Int J Syst Bacteriol 39, 224-229.

Felsenstein, J. (1983). Parsimony in systematics: biological and statistical issues. Annu Rev Ecol Syst 14, 313-333.

Gaunt, M. W., Turner, S. L., Rigottier-Gois, L., Lloyd-Macgilp, S. A. \& Young, J. P. W. (2001). Phylogenies of atpD and recA support the small subunit rRNA-based classification of rhizobia. Int J Syst Evol Microbiol 51, 2037-2048.

Höfle, M. G. (1990). Transfer RNAs as genotypic fingerprints of eubacteria. Arch Microbiol 153, 299-304.

Igual, J. M., Valverde, A., Rivas, R., Mateos, P. F., RodríguezBarrueco, C., Martínez-Molina, E., Cervantes, E. \& Velázquez, E. (2003). Genomic fingerprinting of Frankia strains by PCR-based techniques. Assessment of a primer based on the sequence of $16 \mathrm{~S}$ rRNA gene of Escherichia coli. Plant Soil 254, 115-123.

Jordan, D. C. (1984). Family III. Rhizobiaceae. In Bergey's Manual of Systematic Bacteriology, vol. 1, pp. 234-242. Edited by N. R. Krieg \& J. G. Holt. Baltimore: Williams \& Wilkins.
Jukes, T. H. \& Cantor, C. R. (1969). Evolution of protein molecules. In Mammalian Protein Metabolism, pp. 21-132. Edited by H. N. Munro. London: Academic Press.

Kersters, K. \& De Ley, J. (1984). Genus III. Agrobacterium. In Bergey's Manual of Systematic Bacteriology, vol. 1, pp. 244-254. Edited by N. R. Krieg \& J. G. Holt. Baltimore: Williams \& Wilkins.

Kimura, M. (1980). A simple method for estimating evolutionary rates of base substitutions through comparative studies of nucleotide sequences. J Mol Evol 16, 111-120.

Kumar, S., Tamura, K., Jakobsen, I.-B. \& Nei, M. (2001). Molecular Evolutionary Genetics Analysis Software. Tempe, AZ: Arizona State University.

Kwon, S. W., Park, J. Y., Kim, J. S., Kang, J. W., Cho, Y. H., Lim, C. K., Parker, M. A. \& Lee, G. B. (2005). Phylogenetic analysis of the genera Bradyrhizobium, Mesorhizobium, Rhizobium and Sinorhizobium on the basis of $16 \mathrm{~S}$ rRNA gene and internally transcribed spacer region sequences. Int J Syst Evol Microbiol 55, 263-270.

Mandel, M. \& Marmur, J. (1968). Use of ultraviolet absorbance temperature profile for determining the guanine plus cytosine content of DNA. Methods Enzymol 12B, 195-206.

Martínez-Romero, E. (2003). Diversity of Rhizobium-Phaseolus vulgaris symbiosis: overview and perspectives. Plant Soil 252, 11-23.

Martínez-Romero, E., Segovia, L., Mercante, F. M., Franco, A. A., Graham, P. \& Pardo, M. A. (1991). Rhizobium tropici, a novel species nodulating Phaseolus vulgaris L. beans and Leucaena sp. trees. Int J Syst Bacteriol 41, 417-426.

Moore, L. W., Warren, G. \& Strobel, G. (1979). Involvement of a plasmid in the hairy root disease of plants caused by Agrobacterium rhizogenes. Plasmid 2, 617-626.

Moschetti, G., Peluso, A., Protopapa, A., Anastasio, M., Pepe, O. \& Defez, R. (2005). Use of nodulation pattern, stress tolerance, nodC gene amplification, RAPD-PCR and RFLP-16S rDNA analysis to discriminate genotypes of Rhizobium leguminosarum biovar viciae. Syst Appl Microbiol 28, 619-631.

Plazinski, J., Chen, Y. H. \& Rolfe, B. G. (1985). General method for the identification of plasmid species in fast-growing soil microorganisms. Appl Environ Microbiol 48, 1001-1003.

Rivas, R., Velázquez, E., Valverde, A., Mateos, P. F. \& MartínezMolina, E. (2001). A two primers random amplified polymorphic DNA procedure to obtain polymerase chain reaction fingerprints of bacterial species. Electrophoresis 22, 1086-1089.

Rivas, R., Velázquez, E., Palomo, J.-L., Mateos, P. F., GarciaBenavides, P. \& Martínez-Molina, E. (2002a). Rapid identification of Clavibacter michiganensis subspecies sepedonicus using two primers random amplified polymorphic DNA (TP-RAPD) fingerprints. Eur J Plant Pathol 108, 179-184.

Rivas, R., Velázquez, E., Willems, A., Vizcaíno, N., Subba-Rao, N. S., Mateos, P. F., Gillis, M., Dazzo, F. B. \& Martínez-Molina, E. (2002b). A new species of Devosia that forms a unique nitrogen-fixing rootnodule symbiosis with the aquatic legume Neptunia natans (L. f.) Druce. Appl Environ Microbiol 68, 5217-5222.

Rivas, R., Willems, A., Palomo, J. L., García-Benavides, P., Mateos, P. F., Martínez-Molina, E., Gillis, M. \& Velázquez, E. (2004). Bradyrhizobium betae sp. nov., isolated from roots of Beta vulgaris affected by tumour-like deformations. Int J Syst Evol Microbiol 54, 1271-1275.

Rzhetsky, A. \& Nei, M. (1993). Theoretical foundation of the minimum-evolution method of phylogenetic inference. Mol Biol Evol 10, 1073-1095.

Saitou, N. \& Nei, M. (1987). The neighbor-joining method: a new method for reconstructing phylogenetic trees. Mol Biol Evol 4, 406-425. 
Segovia, L., Young, J. P. W. \& Martínez-Romero, E. (1993). Reclassification of American Rhizobium leguminosarum biovar phaseoli type I strains as Rhizobium etli sp. nov. Int J Syst Bacteriol 43, 374-377.

Tajima, F. \& Nei, M. (1984). Estimation of evolutionary distance between nucleotide sequences. Mol Biol Evol 1, 269-285.

Tamura, K. \& Nei, M. (1993). Estimation of the number of nucleotide substitutions in the control region of mitochondrial DNA in humans and chimpanzees. J Mol Evol 10, 512-526.

Thompson, J. D., Gibson, T. J., Plewniak, F., Jeanmougin, F. \& Higgins, D. G. (1997). The CLUSTAL_X windows interface: flexible strategies for multiple sequence alignment aided by quality analysis tools. Nucleic Acids Res 25, 4876-4882.

Toro, N. \& Olivares, J. (1986). Characterization of a large plasmid of Rhizobium meliloti involved in enhancing nodulation. Mol Gen Genet 202, 331-335.

van Berkum, P., Terefework, Z., Paulin, L., Suomalaien, S., Lindström, K. \& Eardly, B. D. (2003). Discordant phylogenies within the rrn loci of rhizobia. J Bacteriol 185, 2988-2998.

Velázquez, E., Igual, J. M., Willems, A. \& 9 other authors (2001a). Description of Mesorhizobium chacoense sp. nov. that nodulates Prosopis alba in the Chaco Arido region (Argentina). Int J Syst Evol Microbiol 51, 1011-1021.

Velázquez, E., Martínez-Romero, E., Rodríguez-Navarro, D. N., Trujillo, M. E., Daza, A., Mateos, P. F., Martinez-Molina, E. \& Van Berkum, P. (2001b). Characterization of rhizobial isolates of Phaseolus vulgaris by staircase electrophoresis of low molecular weight RNA. Appl Environ Microbiol 67, 1008-1010.

Velázquez, E., Palomo, J. L., Lastra, B., Mateos, P., GarcíaBenavides, P. \& Martínez-Molina, E. (2001c). Rapid identification of Agrobacterium species by staircase electrophoresis of low molecular weight RNA profiles. Eur J Plant Pathol 107, 931-938.

Velázquez, E., Trujillo, M. E., Peix, A., Palomo, J. L., GarcíaBenavides, P., Mateos, P. F., Ventosa, A. \& Martínez-Molina, E. (2001d). Stable low molecular weight RNA analyzed by staircase electrophoresis, a molecular signature for both prokaryotic and eukaryotic microorganisms. Syst Appl Microbiol 24, 490-499.

Velázquez, E., Peix, A., Zurdo-Piñeiro, J. L. \& 7 other authors (2005). The coexistence of symbiosis and pathogenicity-determining genes in Rhizobium rhizogenes strains enables them to induce nodules and tumors or hairy roots in plants. Mol Plant Microbe Interact 18, 1325-1332.

Velázquez, E., Rivas, R., Villar, M., Valverde, A., Peix, A., Mateos, P. F., Velázquez, E. \& Martínez-Molina, E. (2006). A new approach for separating LMW RNA molecules by staircase electrophoresis in non-sequencing gels. Electrophoresis 27, 1732-1738.

Vincent, J. M. (1970). The cultivation, isolation and maintenance of rhizobia. In A Manual for the Practical Study of Root-Nodule Bacteria, pp. 1-13. Edited by J. M. Vincent. Oxford: Blackwell Scientific.

Vinuesa, P., Silva, C., Lorite, M. J., Izaguirre-Mayoral, M. L., Bedmar, E. J. \& Martínez-Romero, E. (2005a). Molecular systematics of rhizobia based on maximum likelihood and Bayesian phylogenies inferred from $r r s, a t p D, r e c A$ and nifH sequences, and their use in the classification of Sesbania microsymbionts from Venezuelan wetlands. Syst Appl Microbiol 28, 702-716.

Vinuesa, P., Silva, C., Werner, D. \& Martínez-Romero, E. (2005b). Population genetics and phylogenetic inference in bacterial molecular systematics: the roles of migration and recombination in Bradyrhizobium species cohesion and delineation. Mol Phylogenet Evol 34, 29-54.

Wayne, L. G., Brenner, D. J., Colwell, R. R. \& 9 other authors (1987). Report of the ad hoc committee on reconciliation of approaches to bacterial systematics. Int J Syst Bacteriol 37, 463-464.

Willems, A., Doignon-Bourcier, F., Goris, J., Coopman, R., De Lajudie, P. \& Gillis, M. (2001). DNA-DNA hybridization study of Bradyrhizobium strains. Int J Syst Evol Microbiol 51, 1315-1322.

Young, J. M., Kuykendall, L. D., Martínez-Romero, E., Kerr, A. \& Sawada, H. (2001). A revision of Rhizobium Frank 1889, with an emended description of the genus, and the inclusion of all species of Agrobacterium Conn 1942 and Allorhizobium undicola de Lajudie et al. 1998 as new combinations: Rhizobium radiobacter, R. rhizogenes, R. rubi, R. undicola and R. vitis. Int J Syst Evol Microbiol 51, 89-103.

Zurdo-Piñeiro, J. L., Velázquez, E., Lorite, M. J., Brelles-Mariño, G., Schröder, E. C., Bedmar, E. J., Mateos, P. F. \& Martínez-Molina, E. (2004). Identification of fast-growing rhizobia nodulating tropical legumes from Puerto Rico as Rhizobium gallicum and Rhizobium tropici. Syst Appl Microbiol 27, 469-477. 